\title{
RECENT JUDICIAL DECISIONS RELATING TO EDUCATION
}

I. N. EDWARDS

University of Chicago

Court decisions constitute an important and heretofore neglected phase of the law of public-school administration. Students of educational law have confined themselves too strictly to the study of legislative enactments. While these, of course, are of supreme importance, yet the fact remains that boards of education, teachers, and others connected with our school system often find it very difficult to determine definitely their legal authority and duties. This is due to the fact that laws must of necessity be somewhat general in their nature and cannot cover every specific activity in which school authorities may wish to engage. Furthermore, school districts as public or municipal corporations possess certain legal authority growing out of the law of their own nature and being, out of the purpose for which they were created. Likewise, their character as corporations limits the types of activity in which they may engage and determines their liability before the law. It often happens, therefore, that differences of opinion arise as to the meaning of the law, and the courts are called upon to decide the matter in controversy. The courts attempt to discover and formulate general principles of interpretation, and in this way judicial decisions come to reveal in a highly significant manner the relation of the state to education.

Within the last two or three years a number of important decisions relating to education have been rendered by the courts. Some of these follow the principles of interpretation already established by the weight of authority; others express a different point of view, while some are cases of first impression.

\section{DISTRICT LIABILITY FOR DAMAGES}

In a recent case, ${ }^{x}$ the city of Baltimore was sued for damages for injuries to a pupil caused by a heavy door falling from its

× Gold v. Baltimore, I4 A.L.R. I389, I I 2 Atl. 588. (Decision rendered January II, I92I.) 
fastenings. It is to be noted that the mayor and the city council of Baltimore are charged by law with the duty of providing necessary buildings and grounds for school purposes, the board of education not being an independent corporation. The Maryland Court of Appeals held that the city was not liable for damages in such cases "upon the theory that the municipality is in the performance of a public or governmental duty and is the instrumentality of the state, exercising a governmental function. In the absence of statute expressly or by necessary implication giving the right of action, the municipality is not liable."

The conclusion reached in this case is supported by two other recent opinions ${ }^{\mathrm{T}}$ and, in fact, by an almost unbroken chain of decisions. In the absence of statutes expressing or implying such liability, the courts very generally apply the rule that neither a school district nor a municipality is liable for injuries growing out of the negligence of its officers, agents, or employees in the management of school affairs. ${ }^{2} \quad$ While exemption or immunity from liability in cases of this kind usually rests upon the theory that school districts and municipalities ${ }^{3}$ are arms of the state performing a public or governmental function, various other reasons are assigned. It is sometimes pointed out that the relation of master and servant does not exist; some courts hold that school corporations have no funds out of which such damages can be paid, "nor have they any power, express or implied, to raise a fund for such purpose, by taxation or otherwise." ${ }^{4}$ Still other authorities place

I Srnka v. Joint District No. 3, I82 N.W. 325 (Supreme Court of Wisconsin, I92 I); Jaked v. Board of Education of the City of Albany, 185 N.Y. Supp. 88, I 33 Misc. 572 (New York, I92I).

${ }^{2}$ Ernst v. City of West Covington, I 6 Ky. 850, 76 S.W. ro89; Daniels v. Board of Education, I9I Mich. 339, 158 N.W. 23; Donovan v. McAlpin, 85 N.Y. 185, 39 Am. Rep. 649; Howard v. Tacoma School Dist. No. Io, 88 Wash. I67, Ann. Cas. 1917D 792; Hill v. City of Boston, I22 Mass. 344, 23 Am. Rep. 332; Wixon v. Newport, I3 R.I. 454; Finch v. Board of Education, 30 Ohio St. 37, 27 Am. Rep. 4I4.

3 The general question of the liability of municipalities for the negligence of their officers is a very complicated one. The courts, however, do not distinguish between municipal corporations proper and school districts when their duties are the same.

4 Freel v. School City of Crawfordsville, I42 Ind. 27; Finch v. Board of Education, 27 Am. Rep. 414; Wiest v. School Dist. No. 24, 68 Ore. 474. 
the exemption upon the ground that school districts "are involuntary corporations, organized, not for profit or gain, but solely for the public benefit."

In a recent case, ${ }^{2}$ however, it was held that where a school board permits the use of school property for other than educational purposes, it may be held liable for injuries growing out of its own negligence. The board of education of the city of New York permitted a community center to use a school gymnasium. A boy who was not a pupil in the school was injured on a defective springboard. It seems that the principal of the school acted as director of the gymnasium while in use as a community center and that his attention had been called to the defect. Judge Page, in rendering the opinion of the court, ruled that by "permitting the community center to use the gymnasium and apparatus for a community use, there was an invitation to those who availed themselves of the privilege to come upon the premises and use the apparatus. Plaintiff was on the premises as an invitee, and not as a mere licensee. The duty, therefore, rested upon the board of education to use reasonable care to keep the premises and appliances in a safe and suitable condition, so that invitees would not be unnecessarily and unreasonably exposed to danger." Otherwise, the district would be liable for injuries. If this decision should prove to establish a precedent, it would have an exceedingly important bearing upon the wider use of the school plant. There really seems, however, to be little justification in equity for distinguishing between injuries sustained by a pupil and by one who is in the school building while engaged in athletic or social exercises. It might be maintained with some show of reason that school boards in permitting the use of school buildings for social centers, public meetings, etc., are not performing a governmental function, but such a view ignores the wider social service of the modern school. In fact, the question might very well be raised as to the justice of not holding school districts liable for injuries growing directly out of the negligence of their officers. In this connection it is interesting to note that in

I Redfield v. School Dist. No. 3, 48 Wash. 85.

${ }^{2}$ Kelly $v$. Board of Education of the City of New York, I80 N.Y. Supp. 796 (1920). 
England public school corporations are held liable for injuries sustained by pupils because of the negligence of school authorities or of teachers in their employ. ${ }^{\mathbf{x}}$

\section{AUTHORITY OF SCHOOL BOARD TO EMPLOY DOCTORS, DENTISTS, AND NURSES}

Recognizing the close relationship between the physical comfort and well-being of pupils and their intellectual and moral development, school boards have very generally undertaken a program of health supervision and, in some cases, of remedial activities. The extent to which school authorities have the legal right to spend the money of the district for activities of this kind, in the absence of specific statutory authority, is an important question and one that has recently come into the courts in a number of jurisdictions. The Supreme Court of Washington (I92I) held ${ }^{2}$ that the board of education of Seattle had no authority to maintain a health clinic for the medical, dental, and surgical treatment of pupils whose parents were unable to give them proper care. The court quoted Judge Dillon on municipal corporations to the effect that it is an undisputed legal principle that municipal corporations possess and can exercise only such powers as are expressly granted or such as are necessarily implied from the grant, or those which are essential to the objects and purposes for which the corporation was created. Though most of the services were rendered without cost to the district, the court was of the opinion that "the rendering of medical, surgical, and dental services to the pupils .... is, and always has been, we think, so foreign to the powers to be exercised by a school district, or its officers, that such power cannot be held to exist, in the absence of express legislative language so providing." There seems to be no doubt that this opinion is supported by the weight of authority. The Supreme Court of Colorado in an opinion $^{3}$ rendered in 1920 reached the same general conclusion.

'Smith ข. Martin (rgı I), 2 K.B. (Eng.) 775, Ann. Cas. rgr2 A 334; Ching v. Surrey County Council (I9IO), I K.B. 736, 26 Times L.R, 355; Shrimpton v. Hertfordshire County Council, I04 L.T.N.S. I45, 27 Times L.R. 25 I.

${ }^{2}$ McGilvra v. Seattle School District No. I, I94 Pac. 8I 7, I2 A.L.R. 913.

${ }^{3}$ Hallett v. Post Printing and Publishing Company, I92 Pac. 658, I2 A.L.R. 919. 
School districts are corporations with very limited powers, and it is a well accepted principle of law that any reasonable doubt as to the existence of power is to be resolved against them by the courts.

It seems very clear, however, that school boards have the authority, even when legislative enactments do not specifically so provide, to employ doctors and nurses for purposes of inspection. Such procedure on the part of the Denver board of education was recently upheld $\mathrm{d}^{\mathrm{x}}$ for two reasons. The first was that the "power of the school board to exclude pupils who do not meet reasonable health requirements, which is undoubted, necessitates the conclusion that they have power (I) to make the requirements and therefore to take expert advice as to what those requirements ought to be and (2) to determine whether the pupil meets them, which requires expert advice and inspection, and therefore they may employ suitable persons to give such advice and make such inspection." The second reason assigned was that the board undoubtedly has the power to provide for the physical as well as for the mental education of the pupils and that "if they provide physical education, they must, within reasonable limits as to the expense and time of pupils, provide for determining what is proper and beneficial for each pupil by all reasonable means, including examination, physical as well as mental, by suitable persons, and for proper physical exercises and development to overcome defects. This should not include medical or surgical treatment for disease. That would be to make infirmaries or hospitals of the schools."

An opinion in a somewhat older case $\mathrm{e}^{2}$ is pertinent in this connection. The school board of Minneapolis employed a nurse for one month to make an inspection of the physical condition of the pupils in certain schools. The comptroller of the city refused to countersign the warrant for her salary. The court upheld the authority of the board to employ the nurse even though the law did not specifically grant such authority.

The purpose of the corporation is to maintain efficient, free, public schools within the city of Minneapolis and, unless expressly restricted, necessarily possesses the power to employ such persons as are required to accomplish

Ibid.

${ }^{2}$ State ex rel. Stoltenberg $v$. Brown, II 2 Minn. 370 (Igro). 
that purpose. Education of a child means much more than merely communicating to it the content of textbooks. But, even if the term were to be so limited, some discretion must be used by the teacher in determining the amount of study each child is capable of. The physical and mental powers of the individual are so interdependent that no system of education, although designed solely to develop mentality, would be complete which ignored bodily health. And this is peculiarly true of children whose immaturity renders their mental efforts largely dependent upon physical conditions. It seems that the school authorities and teachers coming directly in contact with the children should have an accurate knowledge of each child's physical condition, for the benefit of the individual child, for the protection of the other children .... and to permit an intelligent grading of the pupils.

Because of these and other considerations, the court was convinced that the board had the authority, growing out of the purpose for which it was appointed, to employ a nurse for purposes of inspection.

ENFORCEMENT OF AWARD MADE TO TEACHER UNDER WORKMEN'S COMPENSATION ACT

A novel question is presented in the case of Woodcock $v$. Board of Education $\left(\right.$ I $920^{\mathrm{I}}$ as to whether an award made to a teacher under a workmen's compensation act can be enforced in the absence of statutory authority to raise funds for that specific purpose. In the case in point, school districts were constituted employers within the meaning of the Workmen's Compensation Act of Utah. It was further provided that every "school district which is liable to its employees for compensation may insure in the state insurance fund or pay compensation direct." A teacher employed by the board of education of Salt Lake City sustained personal injuries while performing her duties as a teacher. She made application to the Industrial Commission of the state, as the law provided, and was awarded certain compensation. The board, however, refused to pay the award on the ground that it had no funds out of which the claim could be paid and that it was powerless, under the law, to provide the funds or the means with which to pay. The only funds at the disposal of the board, so it was maintained, were those raised for the support and maintenance of the schools, and these "are trust funds and must be devoted strictly to the purposes

I I87 Pac. 181, Io A.L.R. r8I. 
for which they are raised by the processes of taxation, and to divert them to other purposes would constitute a violation of the trust with which they are impressed." The teacher sued for a writ of mandamus commanding the board to pay the award.

After pointing out that school buildings and outhouses might be insured from the support and maintenance fund, the court continued:

Let it be remembered that schools are not, and under the law never were, intended to be maintained for any other purpose than as educational institutions. The teacher, therefore, is, and in the nature of things must be, held to be quite as necessary to the maintenance of schools as educational institutions as are the school buildings in which the schools are kept. In view of the fact, therefore, that the legislature in express terms has included school districts in the Compensation Act, and furthermore provided that those districts shall pay the compensation provided for in the act to their employees, and gave such districts the option of securing the payment of compensation by insuring in the state insurance fund, or by direct payment thereof . . . . the conclusion inevitably follows that the school district represented by the board is liable to the plaintiff for the amount awarded to her by the Commission, and that such amount is payable out of the funds that are raised by taxation for the support and maintenance of schools. . . . . If, however, the board has sufficient funds in the support and maintenance fund for schools to pay plaintiff's claim, it should do so. . . . . By having funds on hand we do not mean that the board must have made a special appropriation to pay compensation, but what we mean is that, if the board has sufficient money in the support and maintenance of schools fund to pay plaintiff's claim, then it has funds with which to pay the same.

The foregoing makes it clear that in Utah funds raised for the support and maintenance of schools may be used to pay awards made under the Workmen's Compensation Act; if the board of education refuses to pay such awards, a writ of mandamus will be issued, provided the plaintiff alleges and proves that the board has such funds. This case is significant in that it is the first, and seems to be the only one up to date, to consider the remedy for the enforcement of awards made to teachers under a workmen's compensation act. It will, therefore, in all probability, establish a principle of interpretation in those states in which school districts have been brought within the meaning of such acts. California, Minnesota, Michigan, Illinois, Iowa, and Montana have statutes 
applicable to school districts in terms very similar to the statute of Utah. ${ }^{\mathrm{I}}$

\section{TEACHERS' SALARY WHILE SCHOOL IS CLOSED}

According to the weight of authority, a teacher is entitled to compensation for the period during which the school is closed by order of the school board because of the prevalence of an epidemic of some contagious disease. ${ }^{2}$ When, however, the schools are closed by order of the health authorities, a somewhat different problem presents itself. In the case of Gregg School Township v. Hinshaw $^{3}$ a teacher brought suit to recover for twenty-seven days' pay while the school was closed because of an epidemic of influenza. The school had been closed, as the law provided it might be, by an order of the health authorities. The opinion of the court was that the teacher could not recover.

It is the general rule that no deduction can be made from a teacher's salary, where a school is closed during the term on account of an epidemic, unless there is a special provision made for such closing in the contract of employment which will allow for such deduction. . . . . In I909 the Legislature amended the Board of Health Act, so that health officers were given power to close schools and churches and forbid gatherings, in order to prevent and stay epidemics. . . . . It was in the exercise of this police power, which had been delegated to it by statute, that the health officials closed the school here involved, and such act was independent of the authority of the township trustee, and entirely beyond his control. The law delegating this authority to the board of health was in force at the time the contract involved was entered into, and it must be deemed to have been made with reference to the law. The law of the land is a part of every contract. It is the rule that, when the performance of a contract becomes impossible, nonperformance is excused, and no damages can be recovered. After the contract was entered into, and when the exigency arose, the health board, in the exercise of the police power delegated to it, closed the school, and the contract for the time that the order was in force was impossible of performance, and hence unenforceable, and there could be no recovery for such time.

Calif. Stat. 1909, chap. I16; Minn. Laws I9r3, chap. 467, par. 34, subd. g; Mich. Pub. Acts rgr 2, p. 2r; Ill. Stat. r9r3, chap. 48, par. I29; Iowa Laws r9r3, chap. I47, par. I, subd. b; Mont. Rev. Code, vol. 3, p. ro7 1.

${ }^{2}$ Dewey v. Union School District, 43 Mich. 480, 38 Am. Rep. 206; McKay v. Barnett, 2 I Utah 239, 60 Pac. I 100; Randolph v. Sanders, 22 Tex. Civ. App. 331, 54 S.W. 62r; Libby v. Douglas, I75 Mass. I28; Smith v. School Dist., 89 Kan. 225; Board of Education v. Couch, 63 Okla. 65I; Carthage v. Gray, ro Ind. App. 428 37 N.E. 1059.

3 I32 N.E. 586 (Ind., 1921). 
The foregoing case raises the much mooted question as to how far impossibility excuses the performance of a contract. An examination of the authorities shows clearly that the rule as here stated is entirely too broad, ${ }^{\mathrm{I}}$ for only certain classes of impossibility excuse performance. However, both reason and authority support the rule that where a school is closed by the order of a board of health having statutory authority, it is closed by operation of the law, and nonperformance of the contract would be justified. ${ }^{2}$ But where a teacher is authorized by the school board to hold himself in readiness, he is entitled to his salary for the period during which the school is closed, even though the school is closed by a board of health in the exercise of its legal authority. ${ }^{3}$ In some jurisdictions, however, where the schools have been closed by order of the board of health, the courts have ruled that the teacher could recover for the time the schools were not in session. ${ }^{4}$

\section{EFFECT OF INTERRUPTION OF SCHOOL SESSION UPON CONTRACTS OTHER THAN WITH TEACHERS}

During the course of the past few years, a number of cases have come into the courts involving the right of an employee, other than a teacher, to recover on a contract while the school is closed. In a recent opinion, ${ }^{5}$ the Supreme Court of Ohio held that one who had

I"At the outbreak of the War in I9I4 the Anglo-American law had therefore recognized at least three well settled classes of supervening impossibility of performance: impossibility due to the destruction of the subject-matter where the contract called for a specific subject-matter as distinguished from a general subject-matter; impossibility due to the death of one of the parties to the contract where the contract was one which provided for personal performance; and impossibility caused by a subsequent change of law, or by the subsequent act of the state by whose law such contract was governed. Whether these classes were exhaustive was another question. There was a strong feeling that there might be other classes of impossibility outside of these three classes." William H. Page, "The Development of the Doctrine of the Impossibility of Performance," I8 Mich. L. Rev. 600. See also "Impossibility of Performance as an Excuse for Breach of Contract," by Frederick C. Woodward, I Col. Law Rev. 529; and "Intervening Impossibility of Performance as Affecting the Obligations of Contracts," by William C. Conlen, 66 Univ. of Penn. Law Rev. 28.

${ }^{2}$ School District v. Howard, 5 Neb. (Unof.) 340, 98 N.W. 666; see also McKay v. Barnett, 21 Utah 239, 60 Pac. I roo.

3 Board of Education v. Couch, 6 A.L.R. 740.

4 Montgomery v. Board of Education, I3I N.E. 479, I5 A.L.R. 715; Carthage v. Gray, 37 N.E. 1059.

5 Montgomery v. Board of Education, I3I N.E. 497, I5 A.L.R. 7 I 5 (I92I). 
contracted with the board to convey pupils to and from school for a period of eight and one-half months might recover at the stipulated rate for the period during which the school was closed by order of the local board of health because of an epidemic of influenza. The plaintiff was required to keep himself and a team of horses in readiness to resume the transportation of pupils on notice, and for this reason the court held that his employment "was continuous throughout all the period in question." It was also pointed out that the contingency which occurred "was one which might well have been foreseen and provided against in the contract but was not. The law will not insert by construction, for the benefit of one of the parties, an exception or condition which the parties, either by design or neglect, have omitted from their own contract." The court refused to distinguish between this type of contract and that of a teacher. "The right to recover under similar circumstances frequently has been sustained in behalf of teachers in the public schools, and no reason is perceived why the same rule should not apply to one occupying such relation to the public schools as does the plaintiff in the case."

In 1920 the Supreme Court of Oregon rendered an opinion very similar to the one just considered. ${ }^{x}$ In this case, the school was closed by order of the state board of health through the county health officers. The plaintiff sued to recover the entire contract price for the transportation of pupils to and from school for a period of nine months. After holding that the state board of health had no authority to close the school in the absence of a specific statutory provision to that effect, the court ruled that the school had been closed by the board of education and not by operation of law.

Neither is it a sequence that the closing of the school would suspend the contract between plaintiff and defendant, which by its terms was confined only to the transporting of pupils to and from school. The contract does not contain any provisions or exceptions, and no order was made by anyone which would in any manner prohibit the carrying out of its terms. As stated in 3 Elliot on Contracts, paragraph $189 \mathrm{r}$ : "The general doctrine that, when a party voluntarily undertakes to do a thing without qualification, performance is not excused because by inevitable accident or other contingency not foreseen it becomes impossible for him to do the act or thing he agreed to do, is well

${ }^{x}$ Crane v. School District No. 14 , 95 Or. 644, 888 Pac. 712. 
settled. As a man consents to bind himself so shall he be bound. When no express or implied provision as to the event of impossibility can be found in the terms or circumstances of the agreement, it is a general rule of construction, founded on the absolute and unqualified terms of the promise, that the promisor remains responsible for damages, notwithstanding the supervening impossibility or hardship.

The same general point of law was involved in the case of Sandry v. Brooklyn School District No. 78. ${ }^{\mathrm{T}}$ The school was closed by order of the county board of health. This was an action to recover compensation stipulated in a driver's contract with the school board for the transportation of pupils to and from school for a period of thirteen weeks while the school was closed because of an epidemic of influenza. There were four separate opinions written. The majority opinion written by Justice Birdzell distinguished between a contract of this kind and a con ract with a teacher on the ground that a teacher "is required to have certain qualifications and to have a certificate as a prerequisite to a right to receive compensation.... The teacher is generally a person coming from outside the district, and the duties involved in the performance of the contract effectually preclude other employment for the period." The driver's contract is of a different character because "the contract is generally entered into between the district and some person within it. Its performance involves little or no preliminary preparation. ... Performance does not require the whole time of the driver. . . . . We think it quite clear that the holding in readiness required of the driver during a period of prolonged suspension involves so little inconvenience on his part that it cannot reasonably be said to be the intention of the contracting parties that he should be paid for such period. In these circumstances the ordinary rule applicable to personal service contracts applies. They are subject to the implied condition, on the one side, of ability to perform, and, on the other, of ability to receive performance. Either party is excused if, without his fault, performance for a period becomes impossible. Such impossibility may arise upon the sickness or death of either party, or the inability of one party to give or receive performance, occasioned by the prevalence of an epidemic."

${ }^{x}$ Sandry v. Brooklyn School District No. 78, I82 N.W. 689, I5 A.L.R. 719 (North Dakota Supreme Court, I921). 
Chief Justice Robinson concurred in the foregoing opinion, but wrote a separate one in which he held that the closing of the school was an act of God, thus creating an impossibility of performance which would excuse the district from all liability under the contract. Justice Bronson, however, in a dissenting opinion, held that the closing of the school acted as a breach of the driver's contract on the part of the district, and that the party aggrieved should "recover the detriment proximately caused through the breach of the contract"; while Justice Grace, dissenting, maintained that the plaintiff should recover the entire amount stipulated in the contract. "We do not regard," he said, "the analysis of the majority opinion, which endeavors to distinguish between this contract and a teacher's contract, as at all correct. Both are contracts, and the principles of law which are applicable to written contracts, which are wholly complete, are as applicable to one as to the other, in the circumstances of this case."

PRIVILEGE IN REPORTS OR STATEMENTS CONCERNING SCHOOL PUPILS AND TEACHERS

The law recognizes from motives of public policy that certain communications and publications are privileged; that is, certain statements which under ordinary circumstances might be held libelous or slanderous are not so held when written or spoken "in connection with some lawful occasion." Privileged communications are of two kinds, those which are absolutely privileged and those which are qualifiedly privileged. ${ }^{\mathbf{x}}$ The former are those communications, such as statements of a member of a legislative body in the performance of his official duty, or the proceedings of a court of law, to which is attached no liability for libel or slander, even though written or spoken with the knowledge that they are false and with malicious intent. Qualified privilege "extends to all communications made bona fide, upon any subject-matter in which the party communicating has an interest, or in reference to which he has a duty, to a person having a corresponding interest or duty. And the privilege embraces cases where the duty is not a legal one, but where it is of a moral or social character of

${ }^{2}$ Cyclopedia of Law and Procedure, XXV, 375, and cases there cited. 
imperfect obligation." ${ }^{\prime}$ Communications of this kind, however, must be free from malice; otherwise, the author may not set up the defense that the communication was privileged.

There are surprisingly few cases involving the right of teachers to make official statements and reports concerning the character of pupils or the right of superintendents or other parties interested to comment in writing, or otherwise, upon the character of teachers. When such statements or reports are made in the course of the performance of a public or professional duty, they are generally held to be privileged, if made in good faith and without malice. Thus a statement made by the principal of a normal school to the keeper of a boarding-house for students, that a certain student was "crazy" and that if the keeper of the boarding-house kept her as a boarder she would lose all of her other boarders, was held to be privileged. ${ }^{2}$ It was the duty of the school authorities to look after the environment of the students and to inspect the houses in which they roomed. The communication was made only after certain charges had been investigated and was clearly within the line of strict professional duty. Likewise, patrons of a public school "for purposes of promoting the public good" may make statements to the proper constituted authorities concerning the character of teachers; and though the statements be defamatory and untrue, yet the author is not liable for libel unless actuated by malice. ${ }^{3}$ But such communications must not depart from the strict line of professional or public duty. In the case of Dawkins $v$. Billingsly, ${ }^{4}$ where the teacher of a district school made an entry in a register, in which should be kept the record of attendance and grades of the pupils, that a certain pupil was a "drag all the time," and "ruined by tobacco and whisky," the court held that the statement was not privileged. The statement was in no way germane to the purposes for which the register was kept; therefore the teacher in making such an entry departed from the line of his professional duty.

I Bacon v. Michigan Central Railroad Company, 66 Mich. I70, 33 N.W. I8r.

${ }^{2}$ Everest v. McKenny, I62 N.W. 277, L.R.A. I917D 779 (Michigan Supreme (ourt, 19r7).

3 Note: 12 A.L.R. 147.

${ }^{4}$ I 72 Pac. 69, I2 A.L.R. I44 (Oklahoma Supreme Court, I9r8). 